\title{
Konferencje Zakładu Socjologii Edukacji Instytutu Socjologii UWr z cyklu „Bezpieczeństwo a edukacja” \\ DOI: 10.19195/2083-7763.9.22
}

Zakład Socjologii Edukacji Instytutu Socjologii Uniwersytetu Wrocławskiego od 2015 roku organizuje cykliczne seminaria, spotkania naukowe i konferencje z cyklu „Bezpieczeństwo a edukacja”. W ciągu ostatnich trzech lat był organizatorem i współorganizatorem łącznie pięciu konferencji z tego cyklu. Problematyka z pogranicza nauk społecznych, bezpieczeństwa i edukacji to jeden z kluczowych zakresów działalności Zakładu Socjologii Edukacji IS UWr. Pod patronatem Ministerstwa Obrony Narodowej 8 czerwca 2016 roku na Wydziale Nauk Społecznych UWr została zorganizowana Ogólnopolska Konferencja Naukowa pt. „Społeczny i edukacyjny wymiar inicjatyw proobronnych w Polsce - stan obecny i perspektywy"; 8 czerwca 2017 odbyła się kolejna Ogólnopolska Konferencja Naukowa we współpracy z Urzędem Marszałkowskim Województwa Dolnośląskiego pt. „Współczesne zagrożenia - bezpieczeństwo - edukacja. Czyli jak uczyć społeczeństwo zasad bezpieczeństwa”, również na Wydziale Nauk Społecznych UWr; 6 czerwca 2018 roku zaś na Wydziale Nauk Społecznych UWr zorganizowano kolejną Ogólnopolską Konferencję Naukową pt. „Instytucje edukacyjne. Bezpieczeństwo - Edukacja”.

Od 2017 roku Zakład Socjologii Edukacji IS UWr jest współorganizatorem cyklu ogólnopolskich konferencji naukowych dotyczących zagrożeń i bezpieczeństwa antyterrorystycznego budynków użyteczności publicznej. W dniach 21-22 listopada 2017 roku w Centrum Konferencyjnym Terminal odbyła się I Ogólnopolska Konferencja „Bezpieczeństwo antyterrorystyczne budynków użyteczności publicznej. Teoria i Praktyka”, rok później - 21-22 listopada 2018 roku - II Ogólnopolska Konferencja i Kongres pt. „Bezpieczeństwo antyterrorystyczne budynków użyteczności publicznej. Zagrożenia i rekomendacje”. Kolejna edycja jest w fazie planowania. Pokrótce zostaną omówione cele i programy wskazanych konferencji.

Konferencja Ogólnopolska „Społeczny i edukacyjny wymiar inicjatyw proobronnych w Polsce — stan obecny i perspektywy", Wydział Nauk Społecznych UWr, 8 czerwca 2016 roku

Ogólnopolska konferencja pt. „Społeczny i edukacyjny wymiar inicjatyw proobronnych w Polsce - stan obecny i perspektywy" została zorganizowana 8 czerwca 2016 roku na Wydziale Nauk Społecznych Uniwersytetu Wrocławskiego. Było to kolejne spotkanie ekspertów z zakresu nauk społecznych, bezpieczeństwa i edukacji zorganizowane przez Zakład Socjologii Edukacji Instytutu Socjologii Uniwersytetu Wrocławskiego. Patronat honorowy nad konferencją objął podsekretarz stanu Ministerstwa Obrony Narodowej prof. dr hab. Wojciech Fałkowski. Partnerami konferencji były: Wyższa Szkoła Bezpieczeństwa w Poznaniu, Wyższa Szkoła Oficerska Wojsk Lądowych we Wrocławiu, Wojskowe Centrum Edukacji Obywatelskiej w Warszawie, Urząd Marszałkowski Województwa Dolnośląskiego, Polskie Towarzystwo Socjologiczne Oddział Wrocławski oraz Zakład Socjologii Grup Dyspozycyjnych Instytutu Socjologii Uniwersytetu Wrocławskiego. Konferencję otworzyli rektor-elekt Uniwersytetu Wrocławskiego — prof. dr hab. Adam Jezierski oraz wicemarszałek Województwa Dolnośląskiego - dr inż. Ewa Mańkowska. 
W ramach konferencji odbyły się dwie sesje: sesja społeczna (dotycząca różnych aspektów związanych z obronnością i inicjatywami proobronymi w obrębie struktur wojskowych, państwowych, w wymiarze ponadregionalnym, regionalnym i lokalnym) oraz sesja edukacyjna (dotycząca podejmowanych inicjatyw edukacyjnych z zakresu bezpieczeństwa i obronności w wymiarze szkoleniowym w wojsku/szkółach wojskowych oraz szkołach cywilnych od szkoły podstawowej po szkoły wyższe). Sesja społeczna składała się z siedmiu wystąpień: prof. dr. hab. Wojciecha Horynia, z Wyższej Szkoły Bezpieczeństwa w Poznaniu pt. Obronność państwa - problem społeczny czy rządowy?, gen. dyw. rez. prof. dr hab. Juliana Maja - dziekana Wydziału Logistyki WAT — pt. Zasadnicze funkcje administracji wojskowej $w$ kształceniu i wychowaniu proobronnym młodzieży szkolnej i studenckiej (wymiar centralny i lokalny), płk. dr. Krzysztofa Gaja, pełniącego wówczas obowiązki Szefa Zarządu Organizacji i Uzupełnień P1 w Sztabie Generalnym WP, pt. Specyfika szkolenia kadr w siłach zbrojnych, płk. dr. hab. Krzysztofa Krakowskiego z Instytutu Obronności Wydziału Zarządzania i Dowodzenia Akademii Obrony Narodowej (obecnie Akademii Sztuki Wojennej) pt. Społeczne inicjatywy proobronne w systemie przygotowań obronnych państwa, Waldemara Zubka - dyrektora Biura do Spraw Proobronnych MON - pt. Wsparcie $i$ wspótpraca ministerstwa obrony narodowej z organizacjami proobronnymi (na przykładzie funkcjonowania biura do spraw proobronnych MON), płk. Krzysztofa Marciniaka z Zarządu Logistyki P4 w Sztabie Generalnym WP pt. Rola logistyki w inicjatywach proobronnych i dr. Juliusza Piwowarskiego - rektora Wyższej Szkoły Bezpieczeństwa Publicznego i Indywidualnego w Krakowie - z bardzo oryginalnym tematem wykładu pt. Polskie echa japońskiej koncepcji kultury bezpieczeństwa. Po wysłuchaniu prelegentów odbyła się dyskusja, żywo kontynuowana w trakcie przerwy obiadowej.

Po przerwie rozpoczęły się obrady sesji edukacyjnej, w której było sześć wystąpień, wśród nich między innymi dr. Radosława Tyślewicza - pełnomocnika Rektora AMW ds. Studentów i Doktorantów z Wydziału Dowodzenia i Operacji Morskich Akademii Marynarki Wojennej i jednocześnie szefa Szkolenia Wojskowego Studentów Cywilnych AMW pt. Cywilne kierunki studiów a szkolnictwo wojskowe - wymiar społeczny dla bezpieczeństwa, następnie oficera Jednostki Wojskowej Komandosów w zastępstwie płk. Wiesława Kukuły - wówczas dowódcy Jednostki Wojskowej Komandosów - pt. Ośrodek Szkolenia Wojsk Specjalnych - koncepcja i perspektywy wdrożenia, prof. dr hab. Aleksandry Skrabacz - dyrektor Wojkkowego Centrum Edukacji Obywatelskiej/Akademii Obrony Narodowej (obecnie Akademii Sztuki Wojennej) pt. Fenomen klas mundurowych w Polsce - aspekt społeczno-edukacyjny i ponownie dr. Radosława Tyślewicza pt. Program minimum dla innowacyjnych projektów szkolenia wojskowego mon vis program szkolenia podstawowego klas mundurowych FOP (Federacji Organizacji Proobronnych). Obrady zakończyło wystąpienie dr Elżbiety Okońskiej z Uniwersytetu Kazimierza Wielkiego w Bydgoszczy pt. Edukacja obywatelska i bezpieczeństwo publiczne - inkubator inicjatyw proobronnych - doświadczenia i poszukiwania oraz dr. Pawła Różańskiego z Akademii Wychowania Fizycznego Białej Podlaskiej pt. Profil wspótczesnych szkoleń proobronnych realizowanych przez studentów służb mundurowych AWF w Białej Podlaskiej. Obrady obu sesji konferencji zakończyła dyskusja, która była kontynuowana jeszcze kilka godzin później.

Z inspiracji spotkania ekspertów i omawianej w ramach konferencji problematyki powstała publikacja pt. Społeczne i edukacyjne aspekty inicjatyw proobronnych $w$ Polsce. Stan 
obecny $i$ perspektywy ${ }^{1}$. Jest to już trzecia publikacja poświęcona społecznym i edukacyjnym aspektom bezpieczeństwa, która powstała z inicjatywy Zakładu Socjologii Edukacji Instytutu Socjologii UWr. Pierwsza, pt. Edukacja dla bezpieczeństwa wobec specyfiki szkolenia grup dyspozycyjnych - wybrane aspekty ${ }^{2}$, i druga, pt. Edukacja dla bezpieczeństwa w różnych wymiarach i kontekstach. Formacje militarne i paramilitarne wobec wyzwań edukacyjnych $^{3}$, zostały wydane w 2014 roku w Wydawnictwie Uniwersytetu Wrocławskiego. Wszystkie trzy należą do serii „Socjologia”. Analogicznie do struktury konferencji monografia Społeczne i edukacyjne aspekty inicjatyw proobronnych $w$ Polsce została podzielona na dwie części: aspekty społeczne i aspekty edukacyjne.

Konferencja Ogólnopolska „Współczesne zagrożenia — bezpieczeństwo — edukacja. Czyli jak uczyć społeczeństwo zasad bezpieczeństwa? Dzieci — młodzież — dorośli — ludzie", Wydział Nauk Społecznych UWr, 8 czerwca 2017 roku

Ogólnopolska konferencja pt. „Współczesne zagrożenia — bezpieczeństwo - edukacja” została zorganizowana 8 czerwca 2017 roku na Wydziale Nauk Społecznych Uniwersytetu Wrocławskiego. Było to kolejne coroczne spotkanie ekspertów z zakresu nauk społecznych, bezpieczeństwa i edukacji zorganizowane przez Zakład Socjologii Edukacji Instytutu Socjologii Uniwersytetu Wrocławskiego i Urząd Marszałkowski Województwa Dolnośląskiego. Patronat honorowy nad konferencją objął marszałek województwa dolnośląskiego Paweł Hreniak. Partnerami konferencji były: Wyższa Szkoła Oficerska Wojsk Lądowych we Wrocławiu, Wojskowe Centrum Edukacji Obywatelskiej w Warszawie, Urząd Marszałkowski Województwa Dolnośląskiego, Polskie Towarzystwo Socjologiczne Oddział Wrocławski, Sekcja Socjologii Młodzieży i Edukacji Polskiego Towarzystwa Socjologicznego, Zakład Socjologii Grup Dyspozycyjnych Instytutu Socjologii Uniwersytetu Wrocławskiego oraz Dolnośląski Ośrodek Doskonalenia Nauczycieli we Wrocławiu. Konferencję otworzyli: rektor Uniwersytetu Wrocławskiego - prof. dr hab. Adam Jezierski oraz wicemarszałek województwa dolnośląskiego - dr inż. Ewa Mańkowska, dziekan Wydziału Nauk Społecznych UWr — prof. dr hab. Robert Wiszniowski, dyrektor Instytutu Socjologii UWr - prof. dr hab. Zbigniew Kurcz oraz dyrektor DODN we Wrocławiu - Małgorzata Matusiak. Konferencja miała charakter poznawczy i aplikacyjny. Po powitaniach odbyło się wręczenie wyróżnień i podziękowań II edycji programu „Bezpieczny Dolnoślązak”, którego celem jest aktywizacja dolnośląskich szkół w zakresie edukacji na rzecz bezpieczeństwa.

W ramach konferencji odbyły się łącznie trzy sesje panelowe. W pierwszej z nich, zatytułowanej Wspótczesne zagrożenia, czyli co powinno być przedmiotem edukacji na rzecz bezpieczeństwa i kogo powinna ona dotyczyć? i moderowanej przez prof. Janusza Sztumskiego, prof. Włodzimierza Chojnackiego i prof. Barbarę Wiśniewską-Paź, aktywny udział wzięli: prof. Piotr Mickiewicz, prof. Piotr Kostyło, prof. Krzysztof Czekaj, dr Radosław Tyślewicz, płk dr Jerzy Niepsuj, mjr rez. dr Jarosław Stelmach, nadkom. dr Do-

${ }^{1}$ Społeczne i edukacyjne aspekty inicjatyw proobronnych $w$ Polsce - stan obecny i perspektywy, red. B. Wiśniewska-Paź, „Socjologia” 55, 2016.

${ }^{2}$ Edukacja dla bezpieczeństwa wobec specyfiki szkolenia grup dyspozycyjnych - wybrane aspekty, red. B. Wiśniewska-Paź, „Socjologia” 55, 2014.

${ }^{3}$ Edukacja dla bezpieczeństwa w różnych wymiarach i kontekstach. Formacje militarne i paramilitarne wobec wyzwań edukacyjnych, red. B. Wiśniewska-Paź, „Socjologia” 2014, nr 64. 
minik Hryszkiewicz, dr Henryk Kromołowski. W sesji drugiej, zatytułowanej Jakimi metodami oraz gdzie powinna się odbywać edukacja na rzecz bezpieczeństwa? i moderowanej przez prof. Piotra Mickiewicza, prof. Macieja Szostaka i prof. Barbarę WiśniewskąPaź, uczestniczyli: dr Radosław Tyślewicz, prof. Wojciech Horyń, mjr rez. dr Jarosław Stelmach, dr Elżbieta Okońska, mjr Leszek Kołtun, insp. dr Iwona Klonowska. Ostatni, trzeci panel, pt. Kto powinien uczyć ludzi zasad bezpiecznych zachowań? Kwestia edukacji kadr oraz wspótdziałania nauczycieli ze stużbami militarnymi i pramilitarny$m i$, moderowali płk rez. prof. Wojciech Horyń, dr Radosław Tyślewicz i prof. Barbara Wiśniewska-Paź. Wzięli w nim udział: prof. Włodzimierz Chojnacki, płk dr Jerzy Niepsuj, nadkom. dr Dominik Hryszkiewicz, insp. Andrzej Łuczyszyn, insp. Daniel Głowacz i mjr Leszek Kołtun.

W nawiązaniu do problematyki obrad konferencji przygotowano i opublikowano monografię pt. Współczesne zagrożenia - bezpieczeństwo - edukacja. Czyli jak uczyć społeczeństwo zasad bezpieczeństwa ${ }^{4}$.

Konferencja Ogólnopolska „Instytucje edukacyjne — bezpieczeństwo — edukacja”, Wydział Nauk Społecznych UWr, 6 czerwca 2018 roku

Ogólnopolska konferencja pt. „Instytucje edukacyjne - bezpieczeństwo - edukacja” została zorganizowana 6 czerwca 2018 roku na Wydziale Nauk Społecznych Uniwersytetu Wrocławskiego. Było to kolejne spotkanie ekspertów z zakresu nauk społecznych, bezpieczeństwa i edukacji przygotowane przez Zakład Socjologii Edukacji Instytutu Socjologii Uniwersytetu Wrocławskiego. Patronat honorowy nad konferencją objął rektor Uniwersytetu Wrocławskiego - prof. Adam Jezierski. Partnerami konferencji były: Wydział Nauk o Bezpieczeństwie Akademii Wojsk Lądowych We Wrocławiu, Instytut Nauk Politycznych Wydziału Nauk Społecznych Uniwersytetu Warmińsko-Mazurskiego w Olsztynie, Katedra Kryminologii i Nauk o Bezpieczeństwie, Wydział Prawa, Administracji i Ekonomii UWr, Katedra Socjologii Stosowanej i Dezorganizacji Społecznej IFiS, Uniwersytet Pedagogiczny im. KEN W Krakowie, Zakład Organizacji i Zarządzania, Katedra Zdrowia Publicznego, Wydział Nauk o Zdrowiu Uniwersyteu Medycznego we Wrocławiu, Zakład Socjologii Grup Dyspozycyjnych Instytutu Socjologii UWr, Polskie Towarzystwo Zdrowia Publicznego - Oddział Dolnośląski, Polskie Towarzystwo Socjologiczne - Oddział Wrocławski. Konferencję otworzyli Rektor Uniwersytetu Wrocławskiego oraz dziekan Wydziału Prawa Administracji i Ekonomii UWr - prof. dr hab. Karol Kiczka, dziekan Wydziału Nauk Społecznych UWr - prof. dr hab. Robert Wiszniowski oraz dyrektor Instytutu Socjologii UWr - prof. dr hab. Zbigniew Kurcz.

Wypracowanie systemu efektywnej edukacji społeczeństwa w zakresie bezpiecznych zachowań jest niestety wciaż przed nami. Aby stworzenie systemu było możliwe, oprócz chęci i rozpoznania terenu realizacji zamierzonych celów edukacyjnych konieczna jest wymiana wiedzy i doświadczeń między środowiskiem ekspertów specjalizujących się w zakresie zagrożeń/bezpieczeństwa a kadrą dydaktyczną instytucji edukacyjnych różnego szczebla oraz przyjęcie założenia, że edukacja w tym zakresie powinna rozpocząć się od

4 Współczesne zagrożenia - bezpieczeństwo - edukacja. Czyli jak uczyć społeczeństwo zasad bezpieczeństwa, red. B. Wiśniewska-Paź, Wrocław 2018. 
najmłodszych lat i po wypracowaniu nawyków być kontynuowana - przy wsparciu instytucjonalnym i samodzielnej aktywności w tym zakresie - przez całe życie. Konferencja skierowana była do zainteresowanej problematyką kadry naukowo-dydaktycznej uczelni wyższych (prywatnych i publicznych), dyrektorów szkół, osób prowadzących działalność edukacyjną, nauczycieli, psychologów i pedagogów szkolnych, osób/nauczycieli odpowiedzialnych za realizację programów edukacyjnych z zakresu bezpieczeństwa, przedstawicieli oddziałów urzędów, służb (między innymi policji, straży granicznej) oraz jednostek i uczelni wojskowych, odpowiedzialnych za współpracę ze środowiskiem cywilnym (szkołami/uczelniami) i realizację programów edukacyjnych z zakresu bezpieczeństwa.

Konferencja miała charakter panelowy i składała się z czterech sesji: społecznej, prawnej, edukacyjnej i zdrowotnej. Do każdej z nich zostali zaproszeni eksperci mający wiedzę teoretyczną i praktyczną w dziedzinach będących przedmiotem rozważań i dyskusji poszczególnych sesji. W każdym panelu był przewidziany czas na zadawanie pytań i dyskusję, co było ważne ze względu na możliwość wymiany myśli, doświadczeń i spostrzeżeń. Podobną formę miały również poprzednie spotkania z tego cyklu.

Konferencja rozpoczęła się od sesji społecznej, zatytułowanej $\mathrm{Na}$ jakie zagrożenia narażona jest instytucja szkoły i jej aktorzy (kadra, administracja, uczniowie, rodzice)? Prowadzili ją: prof. Felicjan Bylok, prof. Robert Janik, prof. Barbara Wiśniewska-Paź, zaproszeni eksperci: prof. Bogdan Kosowski, prof. Piotr Mickiewicz, prof. Krzysztof Czekaj, dr Henryk Kromołowski. Sesja prawna, pt. Aspekty prawne zagrożeń i mechanizmy rozwiązań, była prowadzona przez: prof. Macieja Szostaka, prof. Karola Kiczkę, prof. Janusza Sztumskiego i prof. Barbarę Wiśniewską-Paź. W charakterze ekspertów wystąpili: prof. Tomasz Kalisz, dr Ryszard Balicki, dr Krzysztof Wygoda oraz insp. Ryszard Piotrowski. Sesja edukacyjna, pt. Jak uwrażliwiać i jak edukować w zakresie bezpiecznych zachowań (zapobiegania i reagowania)?, była moderowana przez prof. Krzysztofa Czekaja, prof. Włodzimierza Chojnackiego i prof. Barbarę Wiśniewską-Paź. Ekspertami byli: dr Łukasz Srokowski, ppłk rez. mgr inż. Robert Przybyła, mjr dr Leszek Kołtun, Maria Kędzierska/Grzegorz Sontowski, ppłk. W/S dr Krzysztof Jędrzejak i dr Radosław Tyślewicz. Ostatnią sesję — zdrowotną — pt. Zagrożenia zdrowia i życia - wiedza, świadomość, edukacja, reagowanie i przeciwdziałanie moderowali dr Anna Felińczak, dr Beata Zysiak-Christ, dr Henryk Kromołowski i prof. Barbara Wiśniewska-Paź. W charakterze ekspertów wystąpili: dr Monika Wójta-Kempa, mgr Janina Kulińska, dr n. o zdr. Jolanta Grzebieluch, dr n. med. Monika Przestrzelska, dr Anna Kołcz-Trzęsicka, mgr Izabela Bancewicz, Joanna Łoźnicka i Barbara Demków.

W nawiązaniu do poruszanej problematyki konferencji powstała pt. Instytucje edukacyjne - zagrożenia - bezpieczeństwo. Konteksty prawne, społeczne, edukacyjne i zdrowotne ${ }^{5}$.

Nieco inny wymiar tematyczny mają dwie kolejne konferencje, które stanowią osobny cykl: I Ogólnopolska Konferencja „Bezpieczeństwo antyterrorystyczne budynków użyteczności publicznej. Teoria i Praktyka” oraz II Ogólnopolska Konferencja i Kongres pt. „Bezpieczeństwo antyterrorystyczne budynków użyteczności publicznej. Zagrożenia i rekomendacje”.

${ }^{5}$ Instytucje edukacyjne - zagrożenia - bezpieczeństwo. Konteksty prawne, społeczne, edukacyjne i zdrowotne, red. B. Wiśniewska-Paź, „Bezpieczeństwo a Edukacja”, Torun 2018. 
I Ogólnopolska Konferencja „Bezpieczeństwo antyterrorystyczne budynków użyteczności publicznej. Teoria i praktyka", Wrocław, 21-22 listopada 2017 roku

Organizatorami konferencji były: Zakład Socjologii Edukacji UWr, Katedra Kryminologii i Nauk o Bezpieczeństwie WPAiE UWr oraz firma doradczo-szkoleniowa Safety Project, współorganizatorami zaś: Wyższa Szkoła Policji w Szczytnie, Wyższa Szkoła Bankowa we Wrocławiu, Komenda Wojewódzka Policji we Wrocławiu, Okręgowy Inspektorat Służby Więziennej we Wrocławiu oraz Polskie Towarzystwo Bezpieczeństwa Narodowego. Patronat honorowy nad konferencją objął Marszałek Województwa Dolnośląskiego. Patronat medialny objęły: Special OPS, Telewizja Echo Wrocław oraz Wydawnictwo Difin.

Adresatami konferencji byli przedstawiciele oraz eksperci zajmujący się tematyką bezpieczeństwa i antyterroryzmu, ze szczególnym uwzględnieniem zagrożeń budynków użyteczności publicznej, zarządzający bezpieczeństwem w budynkach użyteczności publicznej (infrastrukturą krytyczną, w tym portami lotniczymi, dworcami kolejowymi i autobusowymi, obiektami podlegającymi obowiązkowej ochronie, budynkami administracji publicznej, placówkami oświaty i uczelniami wyższymi, centrami handlowymi, biurowcami, sklepami wielkopowierzchniowymi, kinami, teatrami, muzeami, placówkami bankowymi), a także przedstawiciele instytucji bezpieczeństwa narodowego oraz sektoru ochrony osób i mienia. Podstawowymi celami konferencji były: identyfikacja tendencji rozwoju współczesnych metod i narzędzi zamachów terrorystycznych, ocena podatności obiektów użyteczności publicznej jako celów zamachów terrorystycznych, ocena systemowych rozwiązań w zakresie bezpieczeństwa antyterrorystycznego w wybranych kategoriach obiektów użyteczności publicznej oraz wypracowanie wniosków dotyczących możliwości poprawy przygotowania obiektów użyteczności publicznej do minimalizowania skutków zamachów terrorystycznych — pod względem prawnym, społecznym, organizacyjnym i edukacyjnym. Struktura konferencji oraz jej problematyka dotyczyły czterech aspektów: istoty zagrożeń współczesnym terroryzmem, budynków użyteczności publicznej jako celów zamachów terrorystycznych, uwarunkowań prawnych, instytucjonalnych i społecznych bezpieczeństwa antyterrorystycznego budynków użyteczności publicznej oraz rozwiążań organizacyjnych, prawnych edukacyjnych ochrony antyterrorystycznej w wybranych kategoriach budynków użyteczności publicznej. Wskazana tematyka była przedmiotem obrad konferencyjnych w ramach paneli tematycznych i eksperckich oraz sesji tematycznych. W konferencji wzięło udział około 200 uczestników.

Równolegle do prowadzonego cyklu konferencyjnego powstała specjalna seria wydawnicza „Przestrzeń publiczna - terroryzm - bezpieczeństwo”, w ramach której będą publikowane monografie jedno- i wieloautorskie poruszające problematykę z tego zakresu. W nawiązaniu do problemów poruszanych podczas omawianej konferencji zostały opublikowane dwa tomy w tej serii: Bezpieczeństwo antyterrorystyczne budynków użyteczności publicznej. Analiza - diagnoza - case Study ${ }^{6}$ oraz Bezpieczeństwo antyterrorystyczne budynków użyteczności publicznej. Metody i narzędzia zamachów vs działania antyterrorystyczne i kontrterrorystyczne ${ }^{7}$.

${ }^{6}$ Bezpieczeństwo antyterrorystyczne budynków użyteczności publicznej Analiza - diagnoza case study, red. B. Wiśniewska-Paź, M. Szostak, J. Stelmach, Toruń 2018.

${ }^{7}$ Bezpieczeństwo antyterrorystyczne budynków użyteczności publicznej. Metody i narzędzia zamachów vs działania antyterrorystyczne i kontrterrorystyczne, red. B. Wiśniewska-Paź, M. Szostak, J. Stelmach, Toruń 2018.

Forum Socjologiczne 9, 2018

(C) for this edition by CNS 
|l Ogólnopolska Konferencja i Kongres pt. „Bezpieczeństwo antyterrorystyczne budynków użyteczności publicznej. Zagrożenia i rekomendacje”, Wrocław, 21-22 listopada 2018 roku

Organizatorami konferencji były: Zakład Socjologii Edukacji IS UWr, Katedra Kryminologii i Nauk o Bezpieczeństwie WPAiE UWr, Wyższa Szkoła Bezpieczeństwa Publicznego i Indywidualnego Apeiron w Krakowie oraz firma doradczo-szkoleniowa Safety Project. Współorganizatorami były zaś: Wyższa Szkoła Policji w Szczytnie, Wyższa Szkoła Bankowa we Wrocławiu, Międzynarodowa Wyższa Szkoła Logistyki i Transportu we Wrocławiu, Wydział Politologii i Studiów Międzynarodowych w UMK w Toruniu, Instytut Politologii UO, Zakład Socjologii Grup Dyspozycyjnych IS UWr, Komenda Wojewódzka Policji we Wroclawiu, Wydział Żandarmerii Wojskowej we Wrocławiu i inne instytucje. Patronat medialny nad konferencją objęly: Special OPS, InfoSecurity24.pl, Defence24.pl, Wydawnictwo Adam Marszałek, Wydawnictwo Difin i inne instytucje. Adresatami konferencji, podobnie jak w poprzedniej edycji, były osoby zarządzające bezpieczeństwem w budynkach użyteczności publicznej, przedstawiciele nauki oraz eksperci zajmujący się tematyką bezpieczeństwa i terroryzmu, przedstawiciele instytucji bezpieczeństwa narodowego oraz ochrony osób i mienia, przedstawiciele sektora prywatnego zajmujący się sprzedażą, produkcją lub instalacją sprzętu oraz infrastruktury systemów ochrony, w tym antyterrorystycznej, a także pracownicy unijnych agend i organizacji. Zarówno forma, jak i problematyka konferencji były kontynuacją poprzedniej edycji. Oprócz celów poznawczych ważne było również wyciągnięcie wniosków dotyczących możliwości poprawy przygotowania obiektów użyteczności publicznej do minimalizacji skutków zamachów terrorystycznych oraz przygotowania rekomendacji na potrzeby wiodących instytucji odpowiedzialnych za programowanie bezpieczeństwa, w tym antyterrorystycznego, w naszym kraju, na przykład MSWiA, MON, RCB, ABW, policji, żandarmerii wojskowej. W nawiązaniu do poruszanych problemów przygotowywane są dwa kolejne tomy w serii „Przestrzeń publiczna — terroryzm — bezpieczeństwo”.

Zaspokojenie kluczowej potrzeby współczesnego człowieka - potrzeby bezpieczeństwa — nie jest w żadnym wypadku możliwe bez nieustannej edukacji ( ${ }^{8}$ tym szkoleń). Była już o tym szerzej mowa przy okazji dwóch poprzednich konferencji z tego zakresu, organizowanych w poprzednich latach. Bezpieczeństwo, będąc punktem wyjścia do zaspokajania innych ważnych potrzeb - między innymi przetrwania i rozwoju — jest procesem dającym subiektywne poczucie stabilności i spokoju, postrzegane indywidualnie przez poszczególne podmioty. Wymiar podmiotowy bezpieczeństwa skorelowany jest przy tym z wymiarem strukturalnym ${ }^{9}$. Oba wzajemnie się przenikają i wywierają na siebie wpływ $\mathrm{w}$ aspekcie zarówno zapewnienia, trwania, jak i budowania bezpieczeństwa.

O ile cele i założenia dotyczące potrzeby obronności, bezpieczeństwa i edukacji na rzecz bezpieczeństwa są klarowne i szczytne w swej wymowie literalnej, o tyle z ich praktyczną realizacją bywa różnie. Dotyczy to szkół, instytucji publicznych oraz non profit, ale i wyspecjalizowanych w zakresie obronności i bezpieczeństwa służb militarnych i paramilitarnych - ich szkolenia i rozwoju. Proces profesjonalizacji tych formacji ma zarówno

${ }^{8}$ Por. Edukacja wobec wyzwań XXI wieku, red. I. Wojnar, J. Kubin, Warszawa 1996; Edukacja jest w niej ukryty skarb, Warszawa 1998.

9 A. Pieczywok, Edukacja dla bezpieczeństwa wobec zagrożeń $i$ wyzwań współczesności, Warszawa 2012 , s. 9. 
wady, jak i zalety. Ograniczenia ilościowe nie zawsze idą w parze ze zwiększeniem efektywności oraz intensyfikacją jakościową. Tym niemniej podejmowane są ciekawe inicjatywy, angażowani są ludzie oraz środki, co być może z czasem wyda oczekiwane owoce.

W odniesieniu do strategii bezpieczeństwa państwa ważne jest przyjęcie do wiadomości, że wszelkie doraźne działania na dłuższą metę są mało efektywne, zaleczają skutki, nie rozwiązując problemu. Współczesne zagrożenia - zarówno wewnętrzne, jak i zewnętrzne - są coraz bardziej złożone, często niedookreślone co do skali, znaczenia, kierunku oddziaływania czy pochodzenia ${ }^{10}$. Wymagają zatem zmiany podejścia. Konieczne jest opracowanie nowego paradygmatu nie tylko bezpieczeństwa, lecz także edukacji na rzecz bezpieczeństwa ${ }^{11}$, realizowanego zarówno w ramach instytucji, jak i poza nimi, nie tylko poprzez przekaz wiedzy teoretycznej, lecz także praktycznej. Nie bez znaczenia jest również kwestia samokształcenia (edukacji permanentnej) jednostek i grup oraz jej wymiar formalny i nieformalny. Wiedzę trzeba bowiem nieustannie aktualizować, ponieważ zagrożenia się zmieniają. Tymczasem rzetelna wiedza na ich temat jest podstawą skutecznego zapobiegania i przeciwdziałania im. Przedstawione w tym przeglądzie konferencje, będące okazją do spotkania i wymiany wiedzy i doświadczeń ekspertów ze świata nauki i praktyki, w założeniu mają sprzyjać realizacji tego celu.

Barbara Wiśniewska-Paź

ORCID: 0000-0001-9616-1105

\section{Bibliografia}

Bezpieczeństwo antyterrorystyczne budynków użyteczności publicznej Analiza - diagnoza - case study, red. B. Wiśniewska-Paź, M. Szostak, J. Stelmach, Toruń 2018.

Bezpieczeństwo antyterrorystyczne budynków użyteczności publicznej. Metody i narzędzia zamachów vs działania antyterrorystyczne i kontrterrorystyczne, red. B. Wiśniewska-Paź, M. Szostak, J. Stelmach, Toruń 2018.

Edukacja - jest w niej ukryty skarb, Warszawa 1998.

Edukacja dla bezpieczeństwa $w$ różnych wymiarach i kontekstach. Formacje militarne i paramilitarne wobec wyzwań edukacyjnych, red. B. Wiśniewska-Paź, „Socjologia” 2014, nr 64.

Edukacja dla bezpieczeństwa wobec specyfiki szkolenia grup dyspozycyjnych - wybrane aspekty, red. B. Wiśniewska-Paź, „Socjologia” 55, 2014.

Edukacja wobec wyzwań XXI wieku, red. I. Wojnar, J. Kubin, Warszawa 1996.

Instytucje edukacyjne - zagrożenia - bezpieczeństwo. Konteksty prawne, społeczne, edukacyjne i zdrowotne, red. B. Wiśniewska-Paź, „Bezpieczeństwo a Edukacja”, Toruń 2018.

Pieczywok A., Edukacja dla bezpieczeństwa wobec zagrożeń i wyzwań wspótczesności, Warszawa 2012.

Społeczne i edukacyjne aspekty inicjatyw proobronnych $w$ Polsce - stan obecny i perspektywy, red. B. Wiśniewska-Paź, „Socjologia” 55, 2016.

Współczesne zagrożenia - bezpieczeństwo - edukacja. Czyli jak uczyć społeczeństwo zasad bezpieczeństwa, red. B. Wiśniewska-Paź, Wrocław 2018.

10 Ibidem, s. 14.

${ }^{11}$ Ibidem. 